\title{
Coronavirus disease 2019 (COVID-19)
}

\section{Situation Report - 87}

\section{HIGHLIGHTS}

- No new country/territory/area reported cases of COVID-19 in the past 24 hours.

- Speaking at the COVID-19 media briefing yesterday, WHO Director-General Dr Tedros stressed that our "commitment to public health, science and to serving all the people of the world without fear or favour remains absolute." The Director-General's speech is available here.

- WHO has released a substantial update to its COVID-19 dashboard, offering better data visualization. The news article is available here and the dashboard is available on the WHO COVID-19 webpage here.

- Drinking alcohol does not protect you against COVID-19: existing rules and regulations to protect health and reduce harm caused by alcohol such as restricting access, should be upheld and even reinforced during the outbreak. More on this is available here, and a factsheet on Alcohol and COVID-19 is available here.

- In India, WHO is deploying its national polio surveillance network and other field staff to help with the COVID-19 response Find more on this here.

- Oxygen therapy plays an extremely important role in case management and is briefly explored in the 'Subject in Focus' below.
SITUATION IN NUMBERS

total (new cases in last 24 hours)

\section{Globally}

1991562 confirmed (76647)

130885 deaths (7875)

\section{European Region}

1013093 confirmed (35497)

89317 deaths (4710)

Region of the Americas

707121 confirmed (33760)

30245 deaths (2909)

\section{Western Pacific Region 125571 confirmed (1367) 4239 deaths (38)}

Eastern Mediterranean Region 111432 confirmed (4043) 5532 deaths (137)

South-East Asia Region 21790 confirmed (1503) 990 deaths (54)

\section{African Region}

11843 confirmed (477)

550 deaths (27)

\section{WHO RISK ASSESSMENT}

Global Level VeryHigh

Figure 1. Countries, territories or areas with reported confirmed cases of COVID-19, 16 April 2020

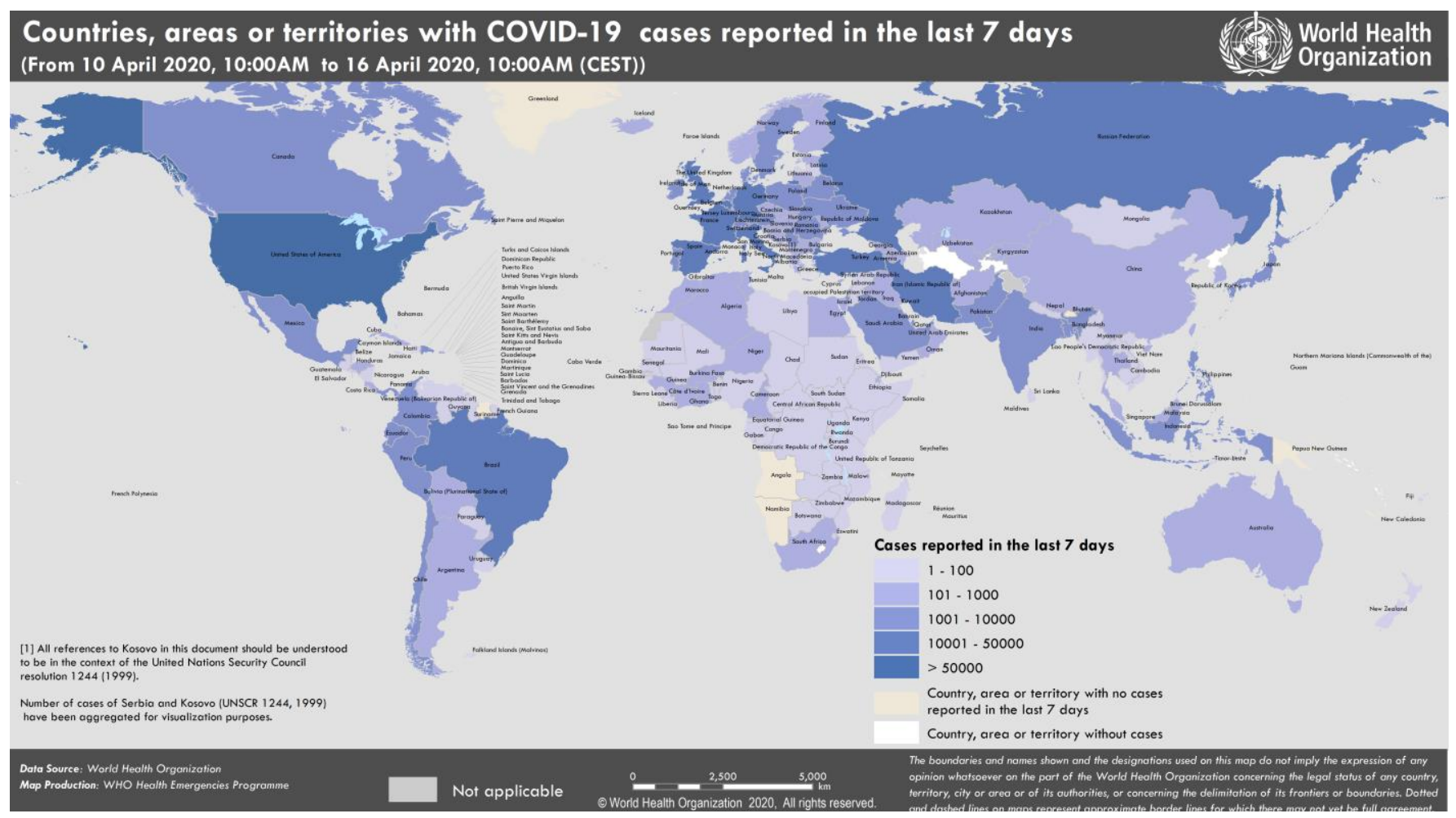


While the majority of patients with COVID-19 have mild or moderated illness, it is estimated that $20 \%$ of affected patients will need oxygen. The ability to boost capacity to deliver oxygen therapy is critical to being able to treat those patients and it has implications for the functioning of the entire system. WHO has recently published "Oxygen sources and distribution for COVID-19 treatment centres", available here, that describes in detail how to surge oxygen systems and distribution.

In many resource-limited settings, oxygen supply and delivery systems are limited and thus rapid gap analysis should be done to inform surge activities. To do so, the COVID-19 Essential Supply Forecast Tool (ESFT), found here, can be used to forecast the total needs of oxygen and associated consumables and accessories (i.e. essential oxygen delivery devices and pulse oximeters). The forecast can then be compared to the existing oxygen supply availability. This method provides a way to identify a contextually appropriate oxygen surge strategy based on structures, capabilities, practices and technologies. Decision-makers can then use this strategy to frame and implement a surge plan. 
SURVEILLANCE

Table 1. Countries, territories or areas with reported laboratory-confirmed COVID-19 cases and deaths. Data as of 16 April 2020*

\begin{tabular}{|c|c|c|c|c|c|c|}
\hline $\begin{array}{l}\text { Reporting Country/ } \\
\text { Territory/Area }^{+}\end{array}$ & $\begin{array}{l}\text { Total } \\
\text { confirmed } \\
\text { ‡ cases }\end{array}$ & $\begin{array}{c}\text { Total } \\
\text { confirmed } \\
\text { new cases }\end{array}$ & $\begin{array}{l}\text { Total } \\
\text { deaths }\end{array}$ & $\begin{array}{c}\text { Total } \\
\text { new } \\
\text { deaths }\end{array}$ & $\begin{array}{l}\text { Transmission } \\
\text { classification }^{\S}\end{array}$ & $\begin{array}{l}\text { Days since last } \\
\text { reported case }\end{array}$ \\
\hline \multicolumn{7}{|c|}{ Western Pacific Region } \\
\hline China & 83797 & 52 & 3352 & 0 & Clusters of cases & 0 \\
\hline Republic of Korea & 10613 & 22 & 229 & 4 & Clusters of cases & 0 \\
\hline Japan & 8582 & 482 & 136 & 17 & Clusters of cases & 0 \\
\hline Australia & 6458 & 42 & 63 & 2 & Clusters of cases & 0 \\
\hline Philippines & 5453 & 230 & 349 & 14 & Clusters of cases & 0 \\
\hline Malaysia & 5072 & 85 & 83 & 1 & Clusters of cases & 0 \\
\hline Singapore & 3699 & 447 & 10 & 0 & Clusters of cases & 0 \\
\hline New Zealand & 1084 & 6 & 9 & 0 & Clusters of cases & 0 \\
\hline Viet Nam & 267 & 1 & 0 & 0 & Clusters of cases & 0 \\
\hline Brunei Darussalam & 136 & 0 & 1 & 0 & Sporadic cases & 5 \\
\hline Cambodia & 122 & 0 & 0 & 0 & Sporadic cases & 4 \\
\hline Mongolia & 30 & 0 & 0 & 0 & Sporadic cases & 1 \\
\hline $\begin{array}{l}\text { Lao People's } \\
\text { Democratic Republic }\end{array}$ & 19 & 0 & 0 & 0 & Sporadic cases & 3 \\
\hline Fiji & 16 & 0 & 0 & 0 & Sporadic cases & 5 \\
\hline Papua New Guinea & 2 & 0 & 0 & 0 & Sporadic cases & 7 \\
\hline \multicolumn{7}{|l|}{ Territories ${ }^{* *}$} \\
\hline Guam & 135 & 0 & 5 & 0 & Clusters of cases & 1 \\
\hline French Polynesia & 55 & 0 & 0 & 0 & Sporadic cases & 2 \\
\hline New Caledonia & 18 & 0 & 0 & 0 & Sporadic cases & 13 \\
\hline $\begin{array}{l}\text { Northern Mariana } \\
\text { Islands } \\
\text { (Commonwealth of } \\
\text { the) }\end{array}$ & 13 & 0 & 2 & 0 & Pending & 1 \\
\hline \multicolumn{7}{|l|}{ European Region } \\
\hline Spain & 177633 & 5092 & 18579 & 523 & Pending & 0 \\
\hline Italy & 165155 & 2667 & 21647 & 578 & Pending & 0 \\
\hline Germany & 130450 & 2866 & 3569 & 315 & Pending & 0 \\
\hline France & 105155 & 2622 & 17146 & 1438 & Pending & 0 \\
\hline The United Kingdom & 98480 & 4603 & 12868 & 761 & Pending & 0 \\
\hline Turkey & 69392 & 4281 & 1518 & 115 & $\begin{array}{l}\text { Community } \\
\text { transmission }\end{array}$ & 0 \\
\hline Belgium & 33573 & 2454 & 4440 & 283 & Pending & 0 \\
\hline Netherlands & 28153 & 734 & 3134 & 189 & Pending & 0 \\
\hline Russian Federation & 27938 & 3448 & 232 & 34 & Clusters of cases & 0 \\
\hline Switzerland & 26336 & 583 & 973 & 73 & $\begin{array}{l}\text { Community } \\
\text { transmission }\end{array}$ & 0 \\
\hline Portugal & 18091 & 643 & 599 & 32 & Pending & 0 \\
\hline Austria & 14370 & 136 & 393 & 9 & Pending & 0 \\
\hline Ireland & 12547 & 1068 & 444 & 38 & Pending & 0 \\
\hline Israel & 12200 & 332 & 126 & 9 & Pending & 0 \\
\hline
\end{tabular}




\begin{tabular}{|c|c|c|c|c|c|c|}
\hline Sweden & 11927 & 482 & 1203 & 170 & Pending & 0 \\
\hline Poland & 7582 & 380 & 286 & 23 & Pending & 0 \\
\hline Romania & 7216 & 337 & 372 & 28 & Pending & 0 \\
\hline Denmark & 6681 & 170 & 309 & 10 & Pending & 0 \\
\hline Norway & 6677 & 111 & 130 & 3 & Pending & 0 \\
\hline Czechia & 6303 & 162 & 166 & 5 & Pending & 0 \\
\hline Serbia & 4873 & 408 & 99 & 5 & Pending & 0 \\
\hline Ukraine & 4162 & 398 & 115 & 7 & Clusters of cases & 0 \\
\hline Belarus & 3728 & 447 & 36 & 3 & Clusters of cases & 0 \\
\hline Luxembourg & 3373 & 66 & 69 & 0 & Pending & 0 \\
\hline Finland & 3237 & 76 & 72 & 8 & Pending & 0 \\
\hline Greece & 2192 & 22 & 102 & 1 & Pending & 0 \\
\hline Republic of Moldova & 2049 & 115 & 46 & 5 & Pending & 0 \\
\hline Croatia & 1741 & 37 & 34 & 3 & Pending & 0 \\
\hline Iceland & 1727 & 7 & 8 & 0 & Pending & 0 \\
\hline Hungary & 1652 & 73 & 142 & 8 & Pending & 0 \\
\hline Estonia & 1402 & 29 & 35 & 4 & Pending & 0 \\
\hline Uzbekistan & 1349 & 135 & 4 & 0 & Clusters of cases & 0 \\
\hline Kazakhstan & 1295 & 20 & 16 & 4 & Pending & 0 \\
\hline Azerbaijan & 1253 & 56 & 13 & 0 & Clusters of cases & 0 \\
\hline Slovenia & 1248 & 28 & 61 & 5 & Pending & 0 \\
\hline Armenia & 1135 & 68 & 18 & 2 & Clusters of cases & 0 \\
\hline $\begin{array}{l}\text { Bosnia and } \\
\text { Herzegovina }\end{array}$ & 1116 & 30 & 41 & 1 & $\begin{array}{l}\text { Community } \\
\text { transmission }\end{array}$ & 0 \\
\hline Lithuania & 1091 & 21 & 29 & 5 & Pending & 0 \\
\hline North Macedonia & 974 & 66 & 45 & 1 & Clusters of cases & 0 \\
\hline Slovakia & 863 & 28 & 6 & 4 & Pending & 0 \\
\hline Bulgaria & 747 & 34 & 36 & 1 & Pending & 0 \\
\hline Cyprus & 715 & 20 & 17 & 0 & Pending & 0 \\
\hline Andorra & 673 & 14 & 33 & 2 & $\begin{array}{l}\text { Community } \\
\text { transmission }\end{array}$ & 0 \\
\hline Latvia & 666 & 9 & 5 & 0 & Pending & 0 \\
\hline Albania & 494 & 19 & 25 & 1 & Clusters of cases & 0 \\
\hline Kyrgyzstan & 466 & 17 & 5 & 0 & Pending & 0 \\
\hline Malta & 399 & 6 & 3 & 0 & Pending & 0 \\
\hline San Marino & 393 & 21 & 36 & 0 & $\begin{array}{l}\text { Community } \\
\text { transmission }\end{array}$ & 0 \\
\hline Georgia & 336 & 30 & 3 & 0 & Clusters of cases & 0 \\
\hline Montenegro & 288 & 0 & 4 & 0 & Clusters of cases & 1 \\
\hline Monaco & 93 & 0 & 0 & 0 & Sporadic cases & 2 \\
\hline Liechtenstein & 81 & 0 & 1 & 0 & Pending & 1 \\
\hline Holy See & 8 & 0 & 0 & 0 & Sporadic cases & 7 \\
\hline \multicolumn{7}{|l|}{ Territories ${ }^{* *}$} \\
\hline Kosovo[1] & 397 & 10 & 9 & 1 & $\begin{array}{l}\text { Community } \\
\text { transmission }\end{array}$ & 0 \\
\hline Isle of Man & 254 & 12 & 2 & 0 & Pending & 0 \\
\hline Guernsey & 223 & 4 & 7 & 1 & Pending & 0 \\
\hline Jersey & 217 & 0 & 6 & 2 & Pending & 1 \\
\hline Faroe Islands & 184 & 0 & 0 & 0 & Pending & 8 \\
\hline Gibraltar & 129 & 0 & 0 & 0 & Pending & 3 \\
\hline
\end{tabular}




\begin{tabular}{|c|c|c|c|c|c|c|}
\hline Greenland & 11 & 0 & 0 & 0 & Pending & 10 \\
\hline \multicolumn{7}{|l|}{ South-East Asia Region } \\
\hline India & 12380 & 941 & 414 & 37 & Clusters of cases & 0 \\
\hline Indonesia & 5136 & 297 & 469 & 10 & $\begin{array}{l}\text { Community } \\
\text { transmission }\end{array}$ & 0 \\
\hline Thailand & 2672 & 29 & 46 & 3 & Pending & 0 \\
\hline Bangladesh & 1231 & 219 & 50 & 4 & Pending & 0 \\
\hline Sri Lanka & 238 & 5 & 7 & 0 & Clusters of cases & 0 \\
\hline Myanmar & 85 & 11 & 4 & 0 & Clusters of cases & 0 \\
\hline Maldives & 21 & 1 & 0 & 0 & Sporadic cases & 0 \\
\hline Nepal & 16 & 0 & 0 & 0 & Sporadic cases & 2 \\
\hline Timor-Leste & 6 & 0 & 0 & 0 & Sporadic cases & 2 \\
\hline Bhutan & 5 & 0 & 0 & 0 & Sporadic cases & 13 \\
\hline \multicolumn{7}{|c|}{ Eastern Mediterranean Region } \\
\hline $\begin{array}{l}\text { Iran (Islamic Republic } \\
\text { of) }\end{array}$ & 76389 & 1512 & 4777 & 94 & $\begin{array}{l}\text { Community } \\
\text { transmission }\end{array}$ & 0 \\
\hline Pakistan & 6505 & 517 & 124 & 17 & Clusters of cases & 0 \\
\hline Saudi Arabia & 5862 & 493 & 79 & 6 & Clusters of cases & 0 \\
\hline United Arab Emirates & 5365 & 432 & 33 & 5 & Pending & 0 \\
\hline Qatar & 3711 & 283 & 7 & 0 & Pending & 0 \\
\hline Egypt & 2505 & 155 & 183 & 5 & Clusters of cases & 0 \\
\hline Morocco & 2024 & 136 & 127 & 1 & Clusters of cases & 0 \\
\hline Bahrain & 1677 & 149 & 7 & 0 & Clusters of cases & 0 \\
\hline Iraq & 1415 & 15 & 79 & 1 & Clusters of cases & 0 \\
\hline Kuwait & 1405 & 50 & 3 & 0 & Clusters of cases & 0 \\
\hline Oman & 1019 & 109 & 4 & 0 & Clusters of cases & 0 \\
\hline Afghanistan & 794 & 24 & 29 & 4 & Clusters of cases & 0 \\
\hline Tunisia & 780 & 33 & 35 & 1 & $\begin{array}{l}\text { Community } \\
\text { transmission }\end{array}$ & 0 \\
\hline Lebanon & 658 & 17 & 21 & 0 & Clusters of cases & 0 \\
\hline Djibouti & 435 & 72 & 2 & 0 & Clusters of cases & 0 \\
\hline Jordan & 401 & 4 & 7 & 0 & Clusters of cases & 0 \\
\hline Somalia & 80 & 20 & 5 & 3 & Sporadic cases & 0 \\
\hline Libya & 48 & 13 & 1 & 0 & Clusters of cases & 0 \\
\hline Syrian Arab Republic & 33 & 4 & 2 & 0 & $\begin{array}{l}\text { Community } \\
\text { transmission }\end{array}$ & 0 \\
\hline Sudan & 32 & 0 & 5 & 0 & Sporadic cases & 1 \\
\hline Yemen & 1 & 0 & 0 & 0 & Pending & 5 \\
\hline \multicolumn{7}{|l|}{ Territories ${ }^{* *}$} \\
\hline $\begin{array}{l}\text { occupied Palestinian } \\
\text { territory }\end{array}$ & 293 & 5 & 2 & 0 & Clusters of cases & 0 \\
\hline \multicolumn{7}{|l|}{ Region of the Americas } \\
\hline $\begin{array}{l}\text { United States of } \\
\text { America }\end{array}$ & 604070 & 25802 & 25871 & 2395 & $\begin{array}{l}\text { Community } \\
\text { transmission }\end{array}$ & 0 \\
\hline Canada & 27540 & 1394 & 954 & 131 & $\begin{array}{l}\text { Community } \\
\text { transmission }\end{array}$ & 0 \\
\hline Brazil & 25262 & 1832 & 1532 & 204 & $\begin{array}{l}\text { Community } \\
\text { transmission }\end{array}$ & 0 \\
\hline Peru & 10303 & 2784 & 230 & 37 & $\begin{array}{l}\text { Community } \\
\text { transmission }\end{array}$ & 0 \\
\hline
\end{tabular}




\begin{tabular}{|c|c|c|c|c|c|c|}
\hline Chile & 8273 & 356 & 94 & 2 & $\begin{array}{l}\text { Community } \\
\text { transmission }\end{array}$ & 0 \\
\hline Ecuador & 7858 & 255 & 388 & 19 & $\begin{array}{l}\text { Community } \\
\text { transmission }\end{array}$ & 0 \\
\hline Mexico & 5399 & 385 & 406 & 74 & $\begin{array}{l}\text { Community } \\
\text { transmission }\end{array}$ & 0 \\
\hline Dominican Republic & 3614 & 328 & 189 & 6 & $\begin{array}{l}\text { Community } \\
\text { transmission }\end{array}$ & 0 \\
\hline Panama & 3574 & 102 & 95 & 1 & $\begin{array}{l}\text { Community } \\
\text { transmission }\end{array}$ & 0 \\
\hline Colombia & 2979 & 127 & 127 & 15 & $\begin{array}{l}\text { Community } \\
\text { transmission }\end{array}$ & 0 \\
\hline Argentina & 2477 & 141 & 108 & 7 & $\begin{array}{l}\text { Community } \\
\text { transmission }\end{array}$ & 0 \\
\hline Cuba & 814 & 48 & 24 & 3 & Clusters of cases & 0 \\
\hline Costa Rica & 618 & 6 & 3 & 0 & Clusters of cases & 0 \\
\hline Uruguay & 492 & 9 & 8 & 0 & Clusters of cases & 0 \\
\hline Honduras & 419 & 12 & 31 & 5 & Clusters of cases & 0 \\
\hline $\begin{array}{l}\text { Bolivia (Plurinational } \\
\text { State of) }\end{array}$ & 397 & 43 & 28 & 0 & Clusters of cases & 0 \\
\hline $\begin{array}{l}\text { Venezuela (Bolivarian } \\
\text { Republic of) }\end{array}$ & 193 & 12 & 9 & 0 & Clusters of cases & 0 \\
\hline Guatemala & 180 & 13 & 5 & 0 & Clusters of cases & 0 \\
\hline Paraguay & 161 & 2 & 8 & 1 & $\begin{array}{l}\text { Community } \\
\text { transmission }\end{array}$ & 0 \\
\hline El Salvador & 159 & 10 & 6 & 0 & Clusters of cases & 0 \\
\hline Trinidad and Tobago & 114 & 1 & 8 & 0 & Sporadic cases & 0 \\
\hline Jamaica & 105 & 32 & 5 & 1 & Clusters of cases & 0 \\
\hline Barbados & 73 & 1 & 5 & 1 & Clusters of cases & 0 \\
\hline Bahamas & 49 & 0 & 8 & 0 & Clusters of cases & 1 \\
\hline Guyana & 48 & 1 & 6 & 0 & Clusters of cases & 0 \\
\hline Haiti & 41 & 1 & 3 & 0 & Clusters of cases & 0 \\
\hline Antigua and Barbuda & 23 & 0 & 2 & 0 & Clusters of cases & 2 \\
\hline Belize & 18 & 0 & 2 & 0 & Sporadic cases & 1 \\
\hline Dominica & 16 & 0 & 0 & 0 & Clusters of cases & 5 \\
\hline Saint Lucia & 15 & 0 & 0 & 0 & Sporadic cases & 4 \\
\hline Grenada & 14 & 0 & 0 & 0 & Clusters of cases & 4 \\
\hline Saint Kitts and Nevis & 14 & 2 & 0 & 0 & Sporadic cases & 0 \\
\hline $\begin{array}{l}\text { Saint Vincent and the } \\
\text { Grenadines }\end{array}$ & 12 & 0 & 0 & 0 & Sporadic cases & 5 \\
\hline Suriname & 10 & 0 & 1 & 0 & Sporadic cases & 12 \\
\hline Nicaragua & 9 & 0 & 1 & 0 & Pending & 3 \\
\hline \multicolumn{7}{|l|}{ Territories } \\
\hline Puerto Rico & 974 & 51 & 51 & 6 & Clusters of cases & 0 \\
\hline Martinique & 158 & 1 & 8 & 0 & Clusters of cases & 0 \\
\hline Guadeloupe & 145 & 0 & 8 & 0 & Clusters of cases & 1 \\
\hline French Guiana & 95 & 7 & 0 & 0 & Clusters of cases & 0 \\
\hline Aruba & 93 & 1 & 1 & 1 & Clusters of cases & 0 \\
\hline Bermuda & 57 & 0 & 5 & 0 & Clusters of cases & 2 \\
\hline Cayman Islands & 54 & 0 & 1 & 0 & Clusters of cases & 1 \\
\hline Sint Maarten & 53 & 1 & 9 & 0 & Clusters of cases & 0 \\
\hline
\end{tabular}




\begin{tabular}{|c|c|c|c|c|c|c|}
\hline $\begin{array}{l}\text { United States Virgin } \\
\text { Islands }\end{array}$ & 51 & 0 & 1 & 0 & Clusters of cases & 5 \\
\hline Saint Martin & 35 & 0 & 2 & 0 & Sporadic cases & 1 \\
\hline Curaçao & 14 & 0 & 1 & 0 & Sporadic cases & 7 \\
\hline $\begin{array}{l}\text { Falkland Islands } \\
\text { (Malvinas) }\end{array}$ & 11 & 0 & 0 & 0 & Clusters of cases & 1 \\
\hline Montserrat & 11 & 0 & 0 & 0 & Sporadic cases & 2 \\
\hline $\begin{array}{l}\text { Turks and Caicos } \\
\text { Islands }\end{array}$ & 10 & 0 & 1 & 0 & Sporadic cases & 1 \\
\hline Saint Barthélemy & 6 & 0 & 0 & 0 & Sporadic cases & 16 \\
\hline $\begin{array}{l}\text { Bonaire, Sint Eustatius } \\
\text { and Saba }\end{array}$ & 4 & 0 & 0 & 0 & Sporadic cases & 1 \\
\hline Anguilla & 3 & 0 & 0 & 0 & Sporadic cases & 12 \\
\hline British Virgin Islands & 3 & 0 & 0 & 0 & Sporadic cases & 15 \\
\hline $\begin{array}{l}\text { Saint Pierre and } \\
\text { Miquelon }\end{array}$ & 1 & 0 & 0 & 0 & Sporadic cases & 8 \\
\hline \multicolumn{7}{|l|}{ African Region } \\
\hline South Africa & 2506 & 91 & 34 & 7 & $\begin{array}{l}\text { Community } \\
\text { transmission }\end{array}$ & 0 \\
\hline Algeria & 2160 & 90 & 336 & 10 & $\begin{array}{l}\text { Community } \\
\text { transmission }\end{array}$ & 0 \\
\hline Cameroon & 855 & 0 & 17 & 2 & Clusters of cases & 1 \\
\hline Côte d'Ivoire & 654 & 16 & 6 & 0 & Clusters of cases & 0 \\
\hline Ghana & 636 & 0 & 8 & 0 & Clusters of cases & 1 \\
\hline Niger & 584 & 14 & 14 & 0 & Clusters of cases & 0 \\
\hline Burkina Faso & 528 & 13 & 28 & 0 & Clusters of cases & 0 \\
\hline Guinea & 404 & 41 & 1 & 1 & Clusters of cases & 0 \\
\hline Nigeria & 373 & 30 & 11 & 1 & Clusters of cases & 0 \\
\hline Mauritius & 324 & 0 & 9 & 0 & Clusters of cases & 3 \\
\hline Senegal & 314 & 15 & 2 & 0 & Clusters of cases & 0 \\
\hline $\begin{array}{l}\text { Democratic Republic } \\
\text { of the Congo }\end{array}$ & 267 & 13 & 22 & 1 & Clusters of cases & 0 \\
\hline Kenya & 225 & 9 & 10 & 1 & Clusters of cases & 0 \\
\hline Mali & 144 & 21 & 13 & 3 & Sporadic cases & 0 \\
\hline Rwanda & 136 & 2 & 0 & 0 & Sporadic cases & 0 \\
\hline Congo & 117 & 43 & 5 & 0 & Clusters of cases & 0 \\
\hline Madagascar & 110 & 0 & 0 & 0 & Clusters of cases & 1 \\
\hline $\begin{array}{l}\text { United Republic of } \\
\text { Tanzania }\end{array}$ & 88 & 35 & 4 & 1 & Sporadic cases & 0 \\
\hline Gabon & 87 & 7 & 1 & 0 & Sporadic cases & 0 \\
\hline Ethiopia & 85 & 3 & 3 & 0 & Sporadic cases & 0 \\
\hline Togo & 77 & 0 & 3 & 0 & Sporadic cases & 1 \\
\hline Liberia & 59 & 0 & 6 & 0 & Sporadic cases & 1 \\
\hline Uganda & 55 & 1 & 0 & 0 & Sporadic cases & 0 \\
\hline Equatorial Guinea & 51 & 10 & 0 & 0 & Sporadic cases & 0 \\
\hline Zambia & 48 & 3 & 2 & 0 & Sporadic cases & 0 \\
\hline Guinea-Bissau & 43 & 3 & 0 & 0 & Sporadic cases & 0 \\
\hline Benin & 35 & 0 & 1 & 0 & Sporadic cases & 4 \\
\hline Eritrea & 35 & 1 & 0 & 0 & Sporadic cases & 0 \\
\hline Mozambique & 28 & 0 & 0 & 0 & Sporadic cases & 1 \\
\hline Chad & 27 & 4 & 0 & 0 & Sporadic cases & 0 \\
\hline
\end{tabular}




\begin{tabular}{|c|c|c|c|c|c|c|}
\hline Zimbabwe & 23 & 5 & 3 & 0 & Sporadic cases & 0 \\
\hline Angola & 19 & 0 & 2 & 0 & Sporadic cases & 7 \\
\hline Eswatini & 16 & 1 & 0 & 0 & Sporadic cases & 0 \\
\hline Malawi & 16 & 0 & 2 & 0 & Sporadic cases & 2 \\
\hline Namibia & 16 & 0 & 0 & 0 & Sporadic cases & 10 \\
\hline Botswana & 13 & 0 & 1 & 0 & Sporadic cases & 6 \\
\hline Sierra Leone & 13 & 2 & 0 & 0 & Sporadic cases & 0 \\
\hline $\begin{array}{l}\text { Central African } \\
\text { Republic }\end{array}$ & 11 & 0 & 0 & 0 & Sporadic cases & 5 \\
\hline Seychelles & 11 & 0 & 0 & 0 & Sporadic cases & 9 \\
\hline Cabo Verde & 10 & 0 & 1 & 0 & Sporadic cases & 2 \\
\hline Gambia & 9 & 0 & 1 & 0 & Sporadic cases & 4 \\
\hline Mauritania & 7 & 0 & 1 & 0 & Sporadic cases & 5 \\
\hline Burundi & 5 & 0 & 0 & 0 & Sporadic cases & 3 \\
\hline $\begin{array}{l}\text { São Tomé and } \\
\text { Príncipe }\end{array}$ & 4 & 0 & 0 & 0 & Pending & 9 \\
\hline South Sudan & 4 & 0 & 0 & 0 & Pending & 4 \\
\hline \multicolumn{7}{|l|}{ Territories $^{* *}$} \\
\hline Réunion & 390 & 0 & 0 & 0 & Clusters of cases & 2 \\
\hline Mayotte & 221 & 4 & 3 & 0 & Clusters of cases & 0 \\
\hline $\begin{array}{l}\text { Subtotal for all } \\
\text { Regions }\end{array}$ & 1990850 & 76647 & 130873 & 7875 & & \\
\hline $\begin{array}{l}\text { International } \\
\text { conveyance (Diamond } \\
\text { Princess) }\end{array}$ & 712 & 0 & 12 & 0 & Not Applicable ${ }^{\dagger+}$ & 31 \\
\hline Grand total & 1991562 & 76647 & 130885 & 7875 & & \\
\hline
\end{tabular}

*Numbers include both domestic and repatriated cases

${ }^{\dagger}$ The designations employed and the presentation of the materialin this publication do not imply the expression of any opinion whatsoeveron the part of WHO concerning the legal status of any country, territory, city or a rea or of its authorities, or concerning the delimitation of its frontiers or boundaries. Dotted and dashed lines on maps represent approximate border lin es for which there may not yet be full agreement. ‡Case classifications are based on WHO case definitions for COVID-19.

\$Transmission classification is based on a process of country/territory/area self-reporting. Classifications are reviewed on a weekly basis and may be upgraded or downgraded as new information becomes available. Not all locations within a given country/terr itory/area are equally affected; countries/territories/areas experiencing multiple types of transmission are classified in the highest category reported. With in a given transmission category, different countries/territories/areas may have differing degrees of transmission as indicated by the differing numbers of cases, recency of cases, and other factors.

Terms:

- No cases: Countries/territories/areas with no confirmed cases (not shown in table)

- Sporadic cases: Countries/territories/areas with one or more cases, imported or locally detected

- Clusters of cases: Countries/territories/areas experiencing cases, clustered in time, geographiclocation and/or by common exposures

- Community transmission: Countries/area/territories experiencing larger outbreaks of local transmission defined through an assessmentof factors including, but not limited to:

- Large numbers of cases not linkable to transmission chains

- Large numbers of cases from sentinel lab surveillance

- Multiple unrelated clusters in several areas of the country/territory/area

** "Territories" include territories, areas, overseas dependencies and other juris dictions of similar status

[1] All references to Kosovo should be understood to be in the context of the United Nations Security Council resolution 1244 (19 99).

t+ As the international conveyance (Diamond Princess) is no longer occupied, transmission classification cannot be applied.

Due to differences in reporting methods, retrospective data consolidation, and reporting delays, the number of new cases may not always reflect the exact difference between yesterday's and today's totals. WHO COVID-19 Situation Reports present official counts of confirmed COVID-19 cases, thus differences between WHO reports and other sources of COVID-19 data using different inclusion criteria and different data cutoff times are to be expected. 


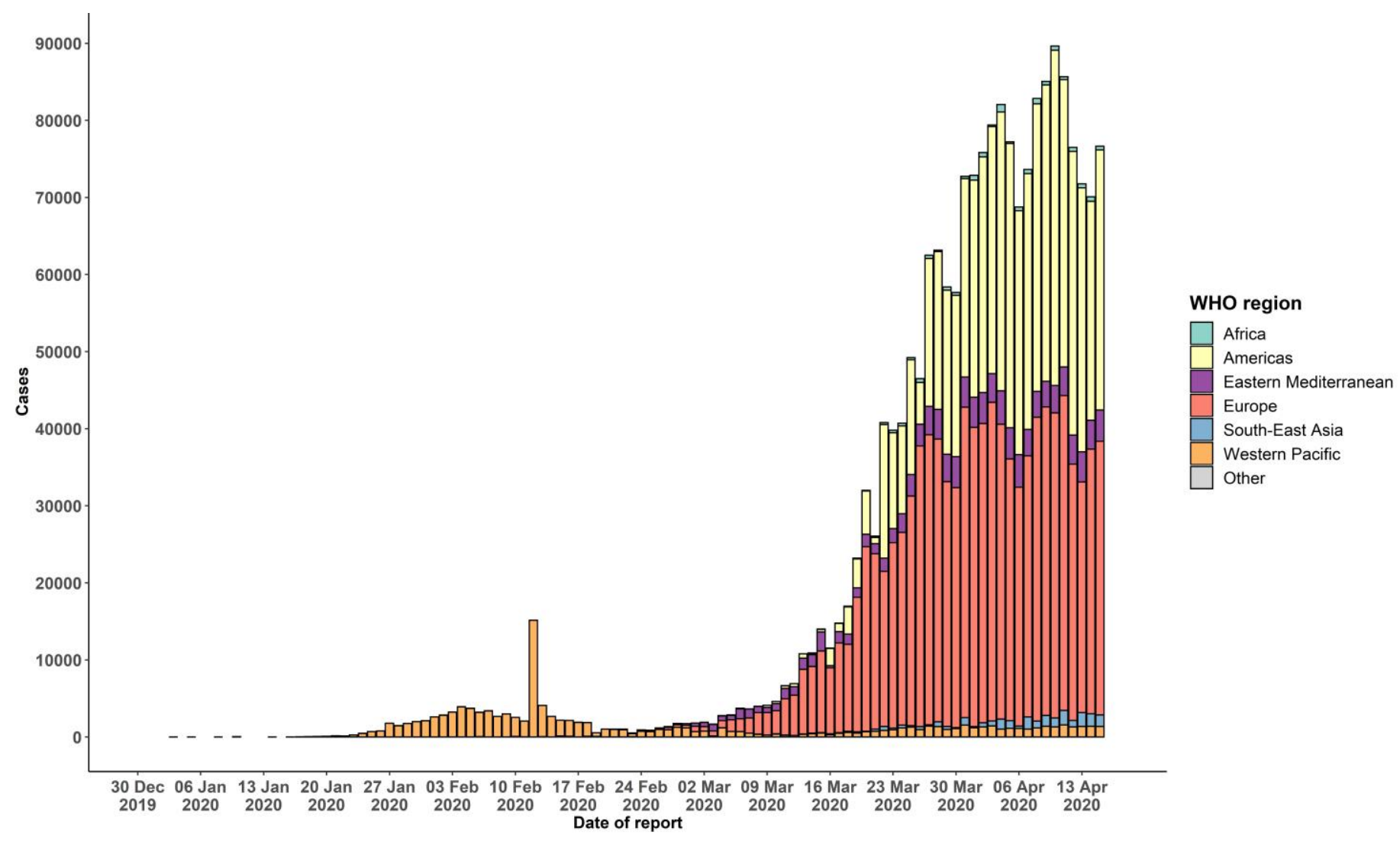

\section{STRATEGIC OBJECTIVES}

WHO's strategic objectives for this response are to:

- Interrupt human-to-human transmission including reducing secondary infections among close contacts and health care workers, preventing transmission amplification events, and preventing further international spread*;

- Identify, isolate and care for patients early, including providing optimized care for infected patients;

- Identify and reduce transmission from the animal source;

- Address crucial unknowns regarding clinical severity, extent of transmission and infection, treatment options, and accelerate the development of diagnostics, therapeutics and vaccines;

- Communicate critical risk and event information to all communities and counter misinformation;

- Minimize social and economic impact through multisectoral partnerships.

*This can be achieved through a combination of public health measures, such as rapid identification, diagnosis and management of the cases, identification and follow up of the contacts, infection prevention and control in health care settings, implementation of health measures for travelers, awareness-raising in the population and risk communication. 


\section{PREPAREDNESS AND RESPONSE}

- To view all technical guidance documents regarding COVID-19, please go to this webpage.

- WHO has developed interim guidance for laboratory diagnosis, advice on the use of masks during home care and in health care settings in the context of COVID-19 outbreak, clinical management, infection prevention and control in health care settings, home care for patients with suspected novel coronavirus, risk communication and community engagement and Global Surveillance for human infection with COVID-19.

- WHO is working closely with International Air Transport Association (IATA) and have jointly developed a guidance document to provide advice to cabin crew and airport workers, based on country queries. The guidance can be found on the IATA webpage.

- WHO has been in regular and direct contact with Member States where cases have been reported. WHO is also informing other countries about the situation and providing support as requested.

- WHO is working with its networks of researchers and other experts to coordinate global work on surveillance, epidemiology, mathematical modelling, diagnostics and virology, clinical care and treatment, infection prevention and control, and risk communication. WHO has issued interim guidance for countries, which are updated regularly.

- WHO has prepared a disease commodity package that includes an essential list of biomedical equipment, medicines and supplies necessary to care for patients with COVID-19.

- WHO has provided recommendations to reduce risk of transmission from animals to humans.

- WHO has published an updated recommendations for international traffic in relation to COVID-19 outbreak.

- WHO has activated the R\&D blueprint to accelerate diagnostics, vaccines, and therapeutics.

- OpenWHO is an interactive, web-based, knowledge-transfer platform offering online courses to improve the response to health emergencies. COVID-19 courses can be found here and courses in additional national languages here. Specifically, WHO has developed online courses on the following topics:

- Introduction to Go.Data - Field data collection, chains of transmission and contact follow-up. The Go.Data tool is available globally to WHO staff, member states and partners to support outbreak investigation, focusing on field data collection, contact tracing and visualisation of chains of transmission.

- A general introduction to emerging respiratory viruses, including novel coronaviruses (available in Arabic, Chinese, English, French, Russian, Spanish, Hindi, Indian Sign Language, Persian, Portuguese, Serbian and Turkish);

- Clinical care for Severe Acute Respiratory Infections (available in English, French, Russian, Indonesian and Vietnamese);

- Health and safety briefing for respiratory diseases - ePROTECT (available in Chinese, English, French, Russian, Spanish, Indonesian and Portuguese);

- Infection Prevention and Control for Novel Coronavirus (COVID-19) (available in Chinese, English, French, Russian, Spanish, Indonesian, Italian, Japanese, Portuguese and Serbian); and

- COVID-19 Operational Planning Guidelines and COVID-19 Partners Platform to support country preparedness and response (available in English and coming soon in additional languages).

- WHO is providing guidance on early investigations, which are critical in an outbreak of a new virus. The data collected from the protocols can be used to refine recommendations for surveillance and case definitions, to characterize the key epidemiological transmission features of COVID-19, help understand spread, severity, spectrum of disease, impact on the community and to inform operational models for implementation of countermeasures such as case isolation, contact tracing and isolation. Several protocols are available here. One such protocol is for the investigation of early COVID-19 cases and contacts (the "First Few X (FFX) Cases and contact investigation protocol for 2019-novel coronavirus (2019-nCoV) infection"). The protocol is designed to gain an early understanding of the key clinical, epidemiological and virological characteristics of the first cases of COVID-19 infection detected in any individual country, to inform the development and updating of public health guidance to manage cases and reduce the potential spread and impact of infection. 


\section{RECOMMENDATIONS AND ADVICE FOR THE PUBLIC}

If you are not in an area where COVID-19 is spreading or have not travelled from an area where COVID-19 is spreading or have not been in contact with an infected patient, your risk of infection is low. It is understandable that you may feel anxious about the outbreak. Get the facts from reliable sources to help you accurately determine your risks so that you can take reasonable precautions (see Frequently Asked Questions). Seek guidance from WHO, your healthcare provider, your national public health authority or your employer for accurate information on COVID -19 and whether COVID-19 is circulating where you live. It is important to be informed of the situation and take appropriate measures to protect yourself and your family (see Protection measures for everyone).

If you are in an area where there are cases of COVID-19 you need to take the risk of infection seriously. Follow the advice of WHO and guidance issued by national and local health authorities. For most people, COVID-19 infection will cause mild illness however, it can make some people very ill and, in some people, it can be fatal. Older people, and those with pre-existing medical conditions (such as cardiovascular disease, chronic respiratory disease or diabetes) are at risk for severe disease (See Protection measures for persons who are in or have recently visited (past 14 days) areas where COVID-19 is spreading).

\section{CASE DEFINITIONS}

WHO periodically updates the Global Surveillance for human infection with coronavirus disease (COVID-19) document which includes case definitions.

For easy reference, case definitions are included below.

\section{Suspect case}

A. A patient with acute respiratory illness (fever and at least one sign/symptom of respiratory disease, e.g., cough, shortness of breath), AND a history of travel to or residence in a location reporting community transmission of COVID-19 disease during the 14 days prior to symptom onset.

OR

B. A patient with any acute respiratoryillness AND having been in contact with a confirmed or probable COVID-19 case (see definition of contact) in the last 14 days prior to symptom onset;

OR

C. A patient with severe acute respiratory illness (fever and at least one sign/symptom of respiratory disease, e.g., cough, shortness of breath; AND requiring hospitalization) AND in the absence of an alternative diagnosis that fully explains the clinical presentation.

\section{Probable case}

A. A suspect case for whom testing for the COVID-19 virus is inconclusive.

a. Inconclusive being the result of the test reported by the laboratory. OR

B. A suspect case for whom testing could not be performed for any reason.

\section{Confirmed case}

A person with laboratory confirmation of COVID-19 infection, irrespective of clinical signs and symptoms.

- Technical guidance for laboratory testing can be found here. 


\section{Definition of contact}

A contact is a person who experienced any one of the following exposures during the 2 days before and the 14 days after the onset of symptoms of a probable or confirmed case:

1. Face-to-face contact with a probable or confirmed case within 1 meter and for more than 15 minutes;

2. Direct physical contact with a probable or confirmed case;

3. Direct care for a patient with probable or confirmed COVID-19 disease without using proper personal protective equipment ${ }^{1} ; \mathrm{OR}$

4. Other situations as indicated by local risk assessments.

Note: for confirmed asymptomatic cases, the period of contact is measured as the 2 days before through the 14 days after the date on which the sample was taken which led to confirmation.

${ }^{1}$ World Health Organization. Infection prevention and control duringhea lth care when COVID-19 is suspected https://www.who.int/publications-detail/infection-prevention-and-control-during-health-care-when-novel-coronavirus-(ncov)infection-is-suspected-20200125 